\title{
Reflection Revisited
}




\section{PERSPECTIVES IN CONTINENTAL PHILOSOPHY \\ John D. Caputo, series editor}

1. Deconstruction in a Nutshell: A Conversation with Jacques Derrida, edited and with a Commentary by John D. Caputo

2. Michael Barber, Ethical Hermeneutics: Rationality in Enrique Dussel's Philosophy of Liberation

3. Michael Strawser, Both/And: Reading Kierkegaard_From Irony to Edification

4. Knowing Other-wise: Philosophy at the Threshold of Spirituality, edited by James H. Olthuis 


\title{
REFLECTION REVISITED \\ Jürgen Habermas's \\ Discursive Theory of Truth
}

\author{
by \\ JAMES SWINDAL
}

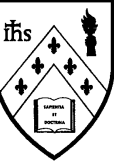

Fordham University Press

New York

1999 


\title{
Copyright @ 1999 Fordham University Press All rights reserved. \\ LC 99-22493
}

\author{
Perspectives in Continental Philosophy, No. 5 \\ Library of Congress Cataloging-in-Publication Data
}

Swindal, James.

Reflection revisited : Jürgen Habermas's discursive theory of truth / by James Swindal.

p. $\mathrm{cm}$. - (Perspectives in continental philosophy, ISSN 1089-3938; no. 5)

Includes bibliographical references and index.

ISBN 13: 978-0-8232-1807-3

1. Habermas, Jürgen-Contributions in concept of truth. 2. Truth.

I. Title. II. Series.

B3258.H324S95 1999

$121^{\prime} .092-D C 21$

99-22493

CIP

Printed in the United States of America 
